\title{
Competing Water Resource Demands in Ethiopia's Federal System: Infancy of the Law toward Integrated Management
}

Abiy Chelkeba*

\begin{abstract}
The Federal Democratic Republic of Ethiopia Constitution confines the power of regional states over water to administration of watercourse that flows within their respective territories. Various proclamations introduce an integrated approach to water resources management through the application of proper and integrated master planning. To this end, a new institutional framework is established through the creation of Basins' Development Authority at national level. The previously established Basin High Councils and Authorities were implementing integrated water management within their respective basins and the powers and obligations of the basin based high councils and authorities are transferred to the newly established National Basin High Council and Basins Development Authority. Some adjustments are necessary due to federalism and issues related to the constitutional framework of water resources that have been overlooked. When the Water Resources Management Proclamation and other water laws are read together with the various provisions of the FRDE Constitution, they lack clarity save the power of the federal government to enact framework legislation over water resources within states' territories. Works undertaken by the federal profit-oriented public enterprises transforming water into an economic good on the lands that are administered by the regional states is an area of on-going controversy. I argue that regional states should claim their constitutional right to levy and collect land use fee from profit making federal public enterprises that are engaged in transforming water into economic good within the framework of integrated water resources management system.
\end{abstract}

\section{Key terms}

Water - Water resources · Federalism - Water law · Integrated water resources management $\cdot$ Ethiopia

DOI http://dx.doi.org/10.4314/mlr.v12i2.1

This article is licensed under a Creative Commons Attribution-NonCommercialNoDerivs (CC BY-NC-ND)

\footnotetext{
* Abiy Chelkeba: LL.B (MU), M.A (MU), LL.M (AAU); Assistant Professor of Law; Amsterdam-Mekele University LL.M Joint programs project coordinator at School of Law, College of Law and Governance, Mekele University; Managing Editor of Mekele University Law Journal. Email: chewabiy@gmail.com

I thank the anonymous reviewers for their comments.
} 


\section{Introduction}

Water is a natural resource with multiple uses. Furthermore, water is essential to human life and ecosystems. These aspects, associated with the 'economic dimension related to some of these uses' (e.g. hydroelectricity, irrigation, navigation, tourism and recreation) and with possible conflicts among users under scarcity, require a very special treatment with regard to water management. ${ }^{1}$ Water is constantly in motion, passing from one state to another, and from one location to another, which makes its rational planning and management complex. ${ }^{2}$ Water is a resource that is of 'direct interest to the entire population, as well as to most ministries of development at federal and state levels, municipalities, private sector, and non-governmental organizations (NGOs) ${ }^{3}$.

Ethiopia is often described as the "water tower of East Africa' ${ }^{4}$ and is home to a large reserve of surface and underground water resource containing significant amount of the continent's existing freshwater. Its territory encompasses several trans-boundary watercourses and basins, including the Nile River basin. The entire country possesses abundant water, for it has 'an annual surface runoff of close to 122 billion cubic meters of water excluding ground water'. ${ }^{5}$ Close to $80-90 \%$ of the country's water resource is found in the four river basins which are Abbay (Blue Nile), Tekeze, Baro Akobo, and OmoGibe. ${ }^{6}$ The aforementioned four major basins have a population density of 30 to 40 percent of Ethiopia's population in the west and the south-west parts of the country. ${ }^{7}$ On the other hand, the water resources available in the east and central river basins (10 to 20 percent) have the highest population density in

\footnotetext{
${ }^{1}$ B. P. F. Braga , R. Flecha, P. Thomas, W. Cardoso \& A. C. Coelho (2009), 'Integrated Water Resources Management in a Federative Country: The Case of Brazil', International Journal of Water Resources Development, 25:4, 611-628, DOI: 10.1080/07900620903273432, p.611

2 Asit K. Biswas (2004), 'Integrated Water Resources Management: A Reassessment', Water International, 29:2, 248-256, DOI: 10.1080/02508060408691775, p. 248.

${ }^{3}$ Ibid.

${ }^{4}$ Gebrehiwot, S.G., Gärdenäs, A.I., Bewket (2014), W. et al. 'The long-term hydrology of East Africa's water tower: statistical change detection in the watersheds of the Abbay Basin', Reg Environ Change, 14: 321. doi:10.1007/s10113-013-0491-x, p. 322.

${ }^{5}$ Ethiopian Water Sector Policy (2001), p.3. See also World Bank (2013), 'Ethiopia second economic update: laying the foundation for achieving middle income status', World Bank, available at: http://documents.worldbank.org/curated/en/2013/06/18594155/ ethiopiasecond-economic-update-laying-foundation-achieving-middle-income-status.

${ }^{6}$ Ethiopian Water Sector Policy (2001), p.3.

${ }^{7}$ Ibid.
} 
Ethiopia (over 60 percent). ${ }^{8}$ This indicates that water is distributed unevenly throughout the territory of the country.

Ethiopia is one of the largest countries in Africa. Organised into a federal republic. It is divided into nine states ${ }^{9}$ and two city administrations. ${ }^{10}$ There are distinct variations in size, population, contribution to national water resources and catchment areas of the basins among the states and this diversity determines the level of investment in the implementation of policies and norms for water use.

The above-mentioned reality of the country suggests that Ethiopia has abundant water and its endowment would naturally benefit from highly developed and well-organized water regulation. It is with the enactment of the 1960 Civil Code that the country began to be concerned about water regulation. However, given the importance of water and the current governance system, there has been little academic scholarship on water resources and federalism since its introduction to the Ethiopian federal system in the early 1990s. Specially, the division of federal and state powers and responsibilities with respect to water require analysis.

In spite of the 1995 FDRE Constitution and subsequent enactments of the Water Resource Management Proclamation ${ }^{11}$, Ethiopia Water Policy, and the River Basin Proclamation ${ }^{12}$, and Powers and Duties of the Executive Organs Proclamation, ${ }^{13}$ Ethiopia's water law is still at its infant stage and is not well equipped to resolve the legal uncertainties surrounding the subject. First, when many provisions of the Water Resource Development Proclamation, Ethiopia

8 Ibid.

${ }^{9}$ Member States of the Federal Democratic Republic of Ethiopia are the following: The State of Tigray, The State of Afar, The State of Amhara, The State of Oromia, The State of Somalia, The State of Benshangul Gumuz, The State of the Southern Nations, Nationalities and Peoples, The State of the Gambela Peoples and The State of the Harari People. See Article 47 of Constitution of the Federal Democratic Republic of Ethiopia, Proclamation No. 1/1995. Federal Negarit Gazeta, Addis Ababa, 1995 Ethiopia (herein after the FDRE Constitution)

${ }^{10}$ The two city administration are the Addis Ababa and Dire Dawa City administrations.

${ }^{11}$ Ethiopia Water Resources Management Proclamation 197/2000, Federal Negarit Gazeta, 61st Year No. 25 Addis Ababa, 9th March 2000 (herein after Water Resources Management Proclamation) .

12 Ethiopia River Basin Councils and Authorities Proclamation 534/ 2007, Federal Negarit Gazeta, 13 ${ }^{\text {th }}$ Year No. 40, Addis Ababa, 2007 (herein after River Basin Proclamation).

${ }^{13}$ Definition of Powers and Duties of the Executive Organs of the Federal Democratic Republic of Ethiopia Proclamation No. 1097/2018, Federal Negarit Gazeta, $25^{\text {th }}$ Year No. 8, Addis Ababa, $29^{\text {th }}$ November, 2018 (hereinafter Powers and Duties of the Executive Organs Proclamation). 
Water Policy, the River Basin Proclamation and Powers and Duties of the Executive Organs Proclamation are read together with various provisions of the FDRE Constitution, many of these provisions are unclear especially those that deal with federal and state water rights and their respective legislative and enforcement powers. There is ambiguity on the respective roles of each levels of government with respect to the management and utilization of water resources as well as problems related to benefits at each level accrued from water sources.

The situation is further complicated by the lack of elaborating regulations and weak organization structure of the river basin authority. There were attempts to establish river based authorities and recently with the coming into power of new administration and its swift reforms, the basin based High Councils and Authorities are replaced with Basin Development Authority. This opens a room for regional states to carry out unilateral development projects that may lay seed for a potential conflict. Second, the inter-governmental relationship between the federal and regional governments with respect to benefit sharing from a planned water projects is not clear. The constitutional rights of regional states to levy and collect land use fee from profit making federal public enterprises -especially those that are engaged in transforming water into an economic and exportable good-is controversial.

This Article attempts to provide an overview of the legal treatment of waters in Ethiopia through the eyes of water resources and federalism. The first section gives a comparative perspective on water law in some selected federal states. Section 2 highlights the historical development of the regulation of water beginning with the 1931 Constitution and continuing through the current FDRE Constitution and subsequent Water Resource Management Proclamations and Regulations. Section 3 presents the constitutional rights of regional states in the administration of water resources and any potential rights that states can claim against profit making federal public enterprise that are engaged in the development and transformation of water resources into economic goods. Sections 4 and 5 examine the current national legislation and administrative institutions on water resources governance among the regional states through an integrated water resource management. The sixth section discusses inter-state water dispute resolution in the context of integrated water resources management. 


\section{Water Resource Management in Some Federal States}

\subsection{Water Resource Management in Federal systems: An overview}

In a federal system of government, there is inevitable fragmentation and overlap in managing water with considerable tension between jurisdictions. While it is the nature of a federal system to divide territory according to political borders, river systems are 'hydrologically interdependent and holistic'. ${ }^{14}$ This is not to say that the management of rivers would be straightforward under a unitary system of government. It is rather to say that 'the existence of multi-level governments with respective constitutional mandate in a federal system complicates inter jurisdictional water management systems' ${ }^{15}$

A recurring issue in the management of water resources has been the role and responsibility of state and federal governments in water use and management. ${ }^{16}$ Historically, states have sought to 'optimize their water extractions with little regard for others, leading to tendencies for over-extraction and widespread environmental degradation which ultimately justify the need for intervention by the federal government'. ${ }^{17}$ There are divisions of powers related to water resources in federations and are quite diverse and complicated. Some jurisdictions substantially assign the power to the federal government, others to the states, while some make it shared power. It is not within the scope of this article to deal with the different modality of arrangements of water resources within a federation in detail, and this section highlights water resources management in two federal states selected for comparative discussion.

The experience relating to legal and institutional aspects of the water governance framework in Australia and Brazil is highlighted in this section. These two countries have similar layers of government (federal and state), and they pursue different institutional approaches in dealing with water governance. The two federal countries are selected based on the models adopted by the counties that have some common elements with the Ethiopian approach to the management of water resources that will be discussed in later sections.

\footnotetext{
${ }^{14}$ Sandford Clark, 'Working paper on Inter-Jurisdictional Water Resources' (Working Paper, Constitutional Commission, 1987) 1, in Paul Kildeal and George Williams (2010), 'The Constitution and the Management of water in Australia's rivers', Sydney Law Review, Vol. 31:595, p.597.

${ }^{15}$ Paul Kildeal and George Williams (2010), 'The Constitution and the Management of water in Australia's rivers', Sydney Law Review, Vol. 31:595, p.597.

${ }^{16}$ Zachary A. Smith (1986), 'Competition for Water Resources: Issues in Federalism', Journal of Land Use and Environmental Law, Vol. 2:177, p. 177.

${ }^{17}$ Margaret Alston, Kerri Whittenbury, Deb Western \& Aaron Gosling (2016), 'Water policy, trust and governance in the Murray-Darling Basin', Australian Geographer, 47:1, 49-64, DOI: 10.1080/00049182.2015.1091056, p. 50.
} 


\subsubsection{Australia}

The Australian Constitutional framework has determined the extent of state and Commonwealth influence over river management. Under its Constitution, the state and territorial governments have primary responsibility for water resources management, with limited powers to the Commonwealth Government. The Australian Constitution left river management largely in the hands of the states. ${ }^{18}$ The federal system requires equality of rights between states, one outcome of which is 'an implied limitation on state legislative powers that could operate as a protection of state water rights' ${ }^{19}$ The Australian Constitution states that 'the power of the parliament to make laws with respect to trade and commerce extends to navigation... ${ }^{20}$ It goes on to state that 'the Commonwealth shall not, by any law or regulation of trade or commerce abridge the rights of state or of the residents therein to the reasonable use of the waters of rivers for conservation or irrigation'. ${ }^{21}$ Regulation of waters within state boundaries is constitutionally within the states' domain, although waters outside the limits of the states fall within the competence of the Commonwealth. ${ }^{22}$ Thus, in the past, the Australian Government has sought other mechanisms to gain state acceptance of the need to change water management policy. ${ }^{23}$

The current framework for Commonwealth/state interaction is defined by a concept of cooperative federalism in environmental and resource management. State and federal government agree on policy and legal objectives; and these are 'then translated into intergovernmental agreements, which in turn leads to law reform in the states and territories'. ${ }^{24}$

After the allocation of water in the Australian Constitution, many attempts to reform the water sector was made. In 1994, the Council of Australian Governments (COAG), an intergovernmental forum, agreed to a Water Reform

${ }_{18}$ Paul Kildeal and George Williams, supra note 15, p. 595.

19 Nicholas Kelly, 'A Bridge? The Troubled History of Inter-State Water Resources and Constitutional Limitation on State Water Use', UNSW Law Journal, Volume 30 (3), 639664, p. 641.

${ }^{20}$ Article 98 section two of the Constitution.

${ }^{21}$ Id., Art. 100.

${ }^{22}$ Lee Godden (2005), 'Water Law Reform in Austria and South Africa: Sustainability, Efficiency and Social Justice', Journal of Environmental Law, Vol 17 No 2, 181-205 doi: 10.1093/envlaw/eqi016, p. 187.

${ }^{23}$ M. D. Young, Environmental effectiveness and economic efficiency of water use in agriculture: The experience of and lessons from the Australian water reform programme, in Wilson Sousa and et al., Water: Drought, Crisis and Governance in Australia and Brazil, Water 2016, 8, 493; doi:10.3390/w8110493, available atwww.mdpi.com/journal/water p. 2.

${ }^{24}$ Lee Godden, supra note 22, p. 187. 
Framework Agreement which recognized 'that action needs to be taken to arrest widespread natural resource degradation in all jurisdictions', and which sought to 'implement a strategic framework to achieve an efficient and sustainable water industry'. ${ }^{25}$ The framework endorsed the following guiding principles. First, water pricing should be consumption-based and operate on the principle of full cost-recovery and removal of cross-subsidies. ${ }^{26}$ Second, water allocations should include reviewable allocations for the environment based on the best scientific information $^{27}$, and restoration of environmental allocations in over allocated systems. Third, water allocations should be clear, separate from land title, $^{28}$ and tradeable. ${ }^{29}$ Finally, the public should be widely consulted. ${ }^{30}$ Furthermore, Integrated Catchment Management was adopted as the basis for water resource planning. ${ }^{31}$

A second phase of reforms began with the negotiation of the National Water Initiative in 2004. ${ }^{32}$ The National Water Initiative aims at setting down a blueprint for national water reform; its broad purpose is to achieve a 'nationallycompatible, market, regulatory and planning based system of managing surface and groundwater resources for rural and urban use that optimizes economic, social and environmental outcomes'. ${ }^{33}$ The National Water Initiative puts in place a program of implementation for the agreed water law reform directions and this process is enhanced by the establishment of a National Water Commission. $^{34}$ The Commission's responsibilities include 'overseeing implementation of reforms, accrediting implementation plans of state and territory governments and overseeing assessment of progress toward reforms'. ${ }^{35}$

${ }^{25}$ COAG, Communique, Attachment A, Hobart, 25 February 1994 in Paul Kildeal and George Williams, supra note 15, p. 599.

${ }^{26}$ CoAG Water Resource Policy clause 3(a)(i). See Lee Godden, supra note 22, p. 189.

${ }^{27}$ Ibid.

${ }^{28}$ Ibid.

${ }^{29}$ Ibid.

30 Ibid.

31 Ibid.

${ }^{32}$ The Intergovernmental Agreement on a National Water Initiative was signed at the June 2004 meeting of the

Council of Australian Governments, with Tasmania and Western Australia joining the agreement in 2005 and 2006 respectively. See Paul Kildeal and George Williams, supra, note 15, p. 599 .

${ }^{33}$ Ibid.

${ }^{34}$ See Schedule C, CoAG Agreement. See Lee Godden, supra note 22, p. 190.

${ }^{35}$ Id., p. 189. 
In 2007, the Commonwealth Parliament passed the Water Act 2007. ${ }^{36}$ The Act set down a detailed regime for the use and management of Australia's water resources, most significantly through requiring the development of a 'Basin Plan'. The purpose of the Plan is 'to provide for the integrated management of water resources in the Murray-Darling Basin'. ${ }^{37}$ Another important development followed in July 2008, with the decision of the Commonwealth and the Basin States to sign the Intergovernmental Agreement on Murray Darling Basin Reform. ${ }^{38}$ These new arrangements involve 'a substantial shift in power toward the national government and away from the states and the relatively weak provisions for compliance in the Water Act 2007 '. ${ }^{39}$ Its purpose is to 'improve planning and management by addressing the Basin's water and other natural resources as a whole, in the context of a federal-state partnership'. ${ }^{40}$ Key elements of the basin plan include (1) sustainable limits for surface and groundwater, (2) basin-wide environmental objectives, including water quality and salinity targets, (3) rules for a basin-wide water trading regime, (4) requirements for each of the four state sub-plans that will implement the basin plan objectives, and (5) measures that will improve security for water entitlement holders. ${ }^{41}$ Each reform has been marked by 'tension between the need for better coordination, and the requirement to preserve state autonomy'. ${ }^{2}$ Water reforms in Australia will require much greater horizontal and vertical integration and coordination across institutions and stakeholders. ${ }^{43}$

\subsubsection{Brazil}

Brazil is a federal republic consisting of 27 states (including the Federal District). ${ }^{44}$ It is estimated that about $12 \%$ of the world's surface water resources and $53 \%$ of South America's surface water resources are located in Brazil. ${ }^{45}$ The present Brazilian Constitution, promulgated in 1988, brought two important

\footnotetext{
${ }^{36}$ Paul Kildeal and George Williams, supra note 15, p.599.

${ }^{37}$ Ibid.

${ }^{38}$ Id., p.600.

${ }^{39}$ Daniel Connell and R. Quentin Grafton (2011) "Water reform in the Murray-Darling Basin", Water Resources Research, Vol. 47, W00G03, doi:10.1029/2010WR009820, p.6.

${ }^{40}$ Intergovernmental Agreement on Murray-Darling Basin Reform, Preamble. Paul Kildeal and George Williams (2010), supra note 15, p.600.

${ }^{41}$ Daniel Connell and R. Quentin Grafton , supra note 39, p.5.

${ }^{42}$ Paul Kildeal and George Williams, supra note 15, p.600.

${ }^{43}$ Daniel Connell and R. Quentin Grafton, supra note 39, p.8.

${ }^{44}$ Lilian Bechara and Alessandra Magrini (2013), 'The Brazilian Water Resources Management Policy: Fifteen Years of Success and Challenges', Water Resource Management Journal, 27:2287-2302, p. 2292.

45 Reboucas AC (2006), Agua Docc no Mundo e no Brasil: in Aguas Doces no Brasil: capital ecologico, use e conservacao. 1:1-35, $3^{\text {rd }}$ Edition. ISBN 85-86303-41-0 in Lilian Bechara and Alessandra Magrini (2013), Ibid.
} 
innovations regarding water resource management: 'first, water resources fall under both federal and state jurisdiction, second, water is a public asset'. ${ }^{4}$

According to the Brazilian Constitution, the states, and the federal district are jointly responsible for legislation regarding natural resources. ${ }^{47}$ However, the union has the mandate of legislating exclusively with respect to water, fluvial, lake, and coastal navigation. Section 22 allows the states to legislate complementarily through specific legislation regulating these matters. ${ }^{48}$ The same constitution, however, "does not allow the states to legislate", and in effect, "attend the peculiarities of such a large territory as Brazil'. ${ }^{49}$ Section 21XII states that 'the federation shall explore, directly or through authorization, concession, or permission, the hydroelectric potential of the watercourses'. This exploitation, however, 'must be performed in articulation with the states where the development is planned'. 50

Nine years later, in 1997, after wide-ranging debates, and considering the experiences of other countries, the Brazilian Congress passed Law 9,433 (1997), which establishes the National Water Resources Policy and creates the National Water Resources Management System. ${ }^{51}$ The water act defined 'two water management domains: the federal level, for interstate or transboundary water basins; and the state level, for water basins contained wholly within the territory of one state'. ${ }^{52}$ Inspired by the procedures adopted in France, it strives to administer water resources on the basis of the river basin concept, as the management unit. ${ }^{53}$ The Law defines the river basin as 'the territorial unit for water resource planning; reinforcing the concept brought in 1988 by the Constitution that water is a public asset'. ${ }^{54}$ The river basin via the basin plan manages and maximizes 'its use in a rational manner through actions designed

\footnotetext{
${ }^{46}$ Ibid.

${ }^{47}$ Benedito P. F. Braga Jr. (2000), 'The Management of Urban Water Conflicts in the Metropolitan Region of São Paulo', Water International, 25:2, 208-213, DOI: 10.1080/02508060008686820, p.209 citing Section 24-VI of the Brazil Constitution.

${ }^{52}$ Wilson Sousa and et al., (2016), 'Water: Drought, Crisis and Governance in Australia and Brazil', Water, 8, 493; doi:10.3390/w8110493, available atwww.mdpi.com/journal/water p. 6.

${ }^{53}$ Rocine Castelo Do Carvalho and Alessandra Magrini (2006) , 'Conflicts over Water Resource Management in Brazil: A Case Study of Inter-Basin Transfers', Water Resources Management, 20: 193-213, DOI: 10.1007/s11269-006-7377-3, p. 195.

${ }^{54}$ Lilian Bechara and Alessandra Magrini, supra note 44, p. 2295.
} 
to ensure appropriate environmental management'. ${ }^{55}$ The law also stipulates that 'water is a scarce resource, which has economic value, and recognizes the existence of multiple water uses and user rights'. 56

At the institutional level, the Law 9,433/1997 establishes a new organizational framework, 'involving shared and decentralized water resources management'. ${ }^{57}$ This framework is composed of the National Water Resources Council, State Water Resources Councils, River Basin Committees, State Water Resources Management Institutions and Water Agencies.

Two other institutions play a role in the Brazilian water resources management system: water councils and governmental water agencies, both of which are replicated at the state and federal levels. ${ }^{58}$ The water councils are comprised of representatives from the government, water users (companies) and civil society (academy, NGOs), appointed by each sector and established by law. ${ }^{59}$ Different from the committees, they are not limited by a river basin. ${ }^{60}$ They are collegiate structures responsible for developing and reviewing policies and for conflict resolution about water management. ${ }^{61}$ They also conduct discussions about inter-basin and inter-state issues, and even international and transboundary waters at federal level. ${ }^{62}$

The Basin Committees consist of representatives of the Federal, State and Municipal Governments, as well as users and civil entities functioning in the water resource area. ${ }^{63}$ These Committees are 'in charge of organizing discussions of problems related to the river basin, arbitrating disputes, approving the basin plan and establishing the fee mechanisms and the amounts to be charged'. ${ }^{64}$ Appointed under the Water Act, or the state's legislation, these committees were 'intended as innovative decision-making spaces, characterized by a natural territoriality (the watershed), and incorporating a diversity of stakeholders (representatives from civil society, water users, and the government)'. ${ }^{65}$ The integrated water resources management principles have

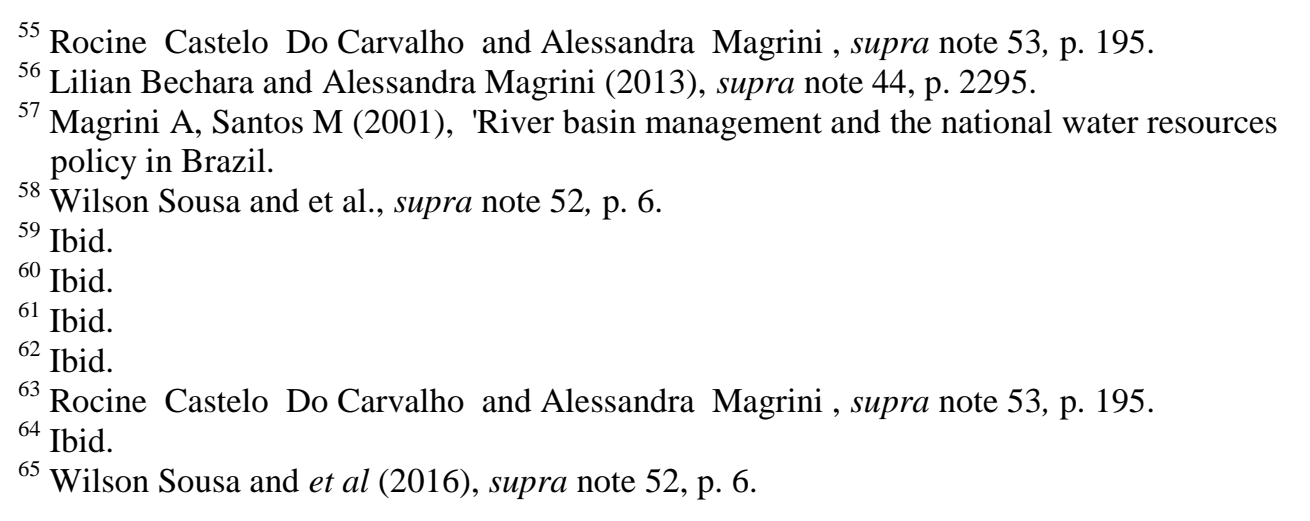


been implemented mainly in the form of 218 state river basin committees and 10 federal committees. ${ }^{66}$

The Water Agencies are 'responsible for implementing the basin plans, as well as issuing the concessions and charging fees for the use of water resources, with the Grantor Authorities being the states for state rivers and the federal government for rivers falling under federal jurisdiction' ${ }^{67}$ The Water Agency serves as the executor of the resolutions adopted by the committees. ${ }^{68}$ It must be noted that after the enactment of Law 9433, in order to facilitate the management of Brazilian water resources, in 2003, Brazil water resources were divided into 12 hydrographic regions. ${ }^{69}$ Each of these regions is "composed of a basin or continuous group of basins and/or sub-basins with similar natural, social and economic characteristics'.70

\section{The Ethiopian Constitution and its Impact on the Water Regime}

The regulation of water resources was a neglected area in Ethiopia. The first 1931 Constitution has not dedicated any single provision pertaining to the regulation of any natural resources. The second 1955 Ethiopian Constitution introduced the regulation and conservation of natural resources, among other things, water. The texts of this Constitutions ${ }^{71}$ assigned dominion over rivers and lakes. ${ }^{72}$ In the same manner, third 1987 Constitution also assigned dominion

${ }^{66}$ Agência Nacional de Águas (ANA). Apoio à Gestão de Recursos Hídricos no Brasil. Available online: http://www.ana.gov.br in Wilson Sousa and et al., supra note 52, p. 6.

${ }^{67}$ Rocine Castelo Do Carvalho and Alessandra Magrini, supra note 53, p. 196.

68 Ibid.

${ }^{69}$ Lilian Bechara and Alessandra Magrini, supra note 44, p. 2293.

${ }^{70}$ Ibid.

${ }^{71}$ Article 10- "The State shall ensure that the ecological balance is maintained and, by ensuring the conservation and development of natural resources, particularly land, water, forest, and wildlife, it shall guarantee their utilization for the benefit of the working people. Article 13- (1)- State ownership is public ownership." (2)- “... Natural resources, in particular land, minerals, water and state, are state property." Art 55 (3)- "Ethiopians have the duty to protect and conserve nature and natural resources, especially to develop forest and to protect and care for soil and water resources."

72 Article 130(a) stipulates that 'the natural resources of, and the sub-soil of the Empire including those beneath its waters, are state domain'. Article 130 (b) also stipulates that 'the natural resources in the waters, forests, land, air, lakes and rivers and ports of the Empire are a sacred trust for the benefit if the present and succeeding generations of the Ethiopian people. The conservation of the said resources are essential for the preservation of the Empire. The Ethiopian Imperial government shall accordingly take such measures as may be necessary and proper, in conformity with the constitution, for the conservation of the said resources'. Article 130(c) further elaborates that 'none of the above mentioned 
over watercourses. The current 1995 FDRE Constitution addresses water in two main ways; it assigns the ownership rights to the commons and legislative and enforcement responsibilities to the federal government and on limited grounds, to the states.

\subsection{Ownership of Water}

Under the FDRE Constitution, all Ethiopian waters are publicly owned. According to Article 40(3) short of expressly mentioning water as such, the right of ownership of all natural resources is exclusively vested in the state and the peoples of Ethiopia. The FDRE Constitution is clear as who owns water and states 'all natural resources (water) is the common property of the nations, nationalities and peoples of Ethiopia (emphasis added). The Water Resource Management Proclamation and Water Resources Policy in the same manner declares that water is the common property of the Ethiopian people and the state. ${ }^{73}$ Water is a public asset, meaning there is no privately owned water in Ethiopia. It must also be clear that regional states or the federal government do not own the water resources that flow through the riverbeds of states. There are no federal or state owned water resources; and the Constitution is very clear that it is the common property of nations, nationalities and peoples of Ethiopia. Common ownership renders the operation of a national water management system difficult, as it, demands coordinated and harmonized actions by the federal and regional governments.

\subsection{Legislative and Administration Jurisdiction}

Water resources fall under both federal and state (legislative and administrative) jurisdictions depending on the interstate or intrastate nature of the river flow. The FDRE Constitution states that the federal government has the power to enact laws for 'the utilization and conservation of land and other natural resources among other things water (emphasis added)'. ${ }^{74}$ The Constitution further elaborates that it is the domain of the federal government and responsibility for the development, administration and regulation of ..... 'waterways and sea transport and .... linking two or more states...(emphasis added) ${ }^{75}$ Inter-state watercourses involve national interest. Development refers to any improvement on the waters, rivers, or lakes. In other words, development of water resources refers to the transformation of water resource into useful

natural resources shall be exploited by any person natural or judicial, including all lands in escheat; and all abandoned properties be it real or personal, as well as all the products of sub-soil, all forests, and all grazing lands, watercourses, lakes and territorial waters are state domain'.

73 See Art. 5 of the Water Resources Management Proclamation.

${ }^{74}$ Id., Art. 51 (5) of the FDRE Constitution.

${ }^{75}$ Id., Art 51 (9). 
social and economic goods. Administration is related to the executive activities of the government on the water bodies. Administration acts can be defined as 'those actions that are necessary to carry out the intent of statutes; those acts required by legislative policy as it is expressed in laws enacted by the legislature'. 76

Regulation refers to the power of federal and state governments to legislate on matters that fall within their respective exclusive jurisdictions and includes any regulatory actions taken by the governments. Thus, inter-state watercourses development, administration and regulation fall within the exclusive domain of the federal government. The federal government 'determines and administers the utilization of the waters or rivers and lakes linking two or more states or crossing the boundaries of the national territorial jurisdiction (emphasis added) . 77

Unlike the Australian Constitution that gives widespread power to the states, the FDRE Constitution gives overwhelming power to the federal government in the management of watercourses in Ethiopia. The federal government has (according to Article 51(11) of the FDRE Constitution) the right to determine and administer water resources if the use by one state of trans-regional water resource affects other states, or if the water resources cross Ethiopia's national boundaries. Other watercourses are under state domain. The contrary reading of the aforementioned provision seems to leave the power of administering waters, rivers, or lakes that are intra-state in nature within the exclusive powers of the state. The Constitution recognizes the right to states to levy and collect taxes on incomes from transport services rendered on waters within their territory. ${ }^{78}$

As far as additional power of the regional states is concerned, there is an exclusive power to administer land and other natural resources (water) found within their territory in accordance with federal laws (emphasis added). ${ }^{79}$ In a federal system, this is what is called a framework power where the federal is empowered to enact framework legislation without exhaustively covering the area and leave the details to be complemented by state laws. Under the Constitution, states have a room to administer water in accordance with federal laws.

At this juncture, a question may arise regarding the power of regions to administer water resources in accordance with federal laws. The issues that are related to this question are whether states can enact laws with regard to

\footnotetext{
${ }^{76}$ www.encyclopedia.com/law/ accessed on 12 June, 2017.

${ }^{77}$ Art 51 (11) of the FDRE Constitution.

${ }^{78}$ Id., Art 97 (5).

${ }^{79}$ Id., Art 52 (2).
} 
administering the water resources, and if yes, whether this amounts to legislating a law. Administration of natural resources in the context of water is meant to take all the necessary actions that are required for the effective management of watercourses including enacting by-laws that supplement the federal laws. Therefore, it will be safe to conclude that regional states have constitutional right in administering water resources and as such, they can enact laws for the proper implementation and administration that suits their actual local conditions. In doing so, administration of water resources must be carried out in conformity with the federal laws.

The FDRE Constitution states that the House of Peoples' Representatives shall 'enact specific laws on matters of utilization of land and other natural resources, of rivers and lakes crossing the boundaries of the national territorial jurisdiction or linking two or more States; as well as on the regulation of water and sea transport, ..... linking two or more states...(emphasis added) ${ }^{80}$ The federal as well as the regional governments have 'duties to hold, on behalf of the People, land and other natural resources and to deploy them for their common benefit and development (emphasis added) ${ }^{,}{ }^{81}$

Subject to the condition that states must follow federal legislation on water governance, each state can regulate water resources laws that apply within its boundaries. For instance, Oromia regional constitution has incorporated a provision on the ownership of natural resources and states that the right to ownership of rural and urban land as well as all natural resource, among other things, water, is exclusively vested in the state and the people of the region (emphasis added). ${ }^{82}$ The same constitution also imposes a duty on the regional government to administer lands and other natural resources of the region in accordance with the laws enacted by the federal government. Regional governments are even allowed to enact laws in relation to inter-state watercourses through the delegation of powers of the federal government as per the River Basin Proclamation and Powers and Duties of the Executive Organs Proclamation. ${ }^{83}$ Although a regional state must follow federal legislation, it can thus enact laws for the water resources within its boundary.

\footnotetext{
${ }^{80}$ Id., Art 55 (2).

Id., Art 89 (5).

82 Art 40 (3) of the Constitution of the Regional State of Oromia, Proclamation No. 1/1995.

${ }^{83}$ See, Article 9 (5) of the River Basin Proclamation. Powers and Duties of the Executive Organs Proclamation has an identical article in Article $32(5)(\mathrm{g})$ in which the Basin Development Authority can 'issue permits applicable to basins' water use and water works, and ensure that the terms of the permits are complied without prejudice to the powers given to Regional States'.
} 


\section{The Power of States over Water Transportation Incomes and Profit-Making Federal Public Enterprises}

The Water Resource Management Proclamation and other water laws lack clarity when they are read together with the provisions of the FRDE Constitution that deal with the federal and state water rights. This difficulty of interpretation, inter alia, relates to works undertaken by federal profit-oriented public enterprises on lands that are administered by the regional states. This section forwards the argument that regional states have the constitutional right to levy and collect land use fee from profit making federal public enterprises that are engaged in transforming water as an economic good within the spirit of the basin based integrated and cooperative water management system.

Water and land are interconnected. Under the FDRE Constitution states have the power to levy and collect land use fee over land thereby providing them usufructuary rights. ${ }^{84}$ States can also 'levy and collect taxes on income from transport services rendered on waters within their territory (emphasis added)' ${ }^{85}$ This is one area of rights of states in surface waters flowing in well defined channels that has become a navigable stream and it is the power of states to enact laws that determines the amount of fee that should be levied and collect the same amount on water transportation services within their territory.

It can be deduced that states do not own the waters or beds of the navigable streams; however, they can exercise rights to levy, collect and administer land use fee rights and income on water transportation rendered within their territory. However, the Ethiopian Constitution has explicitly recognized intergovernmental tax immunity. To this end, Article 100(3) of the Constitution provides 'Neither States nor the Federal Government shall levy and collect taxes on each other's property unless it is a profit making enterprise'. This important constitutional taxation principle puts limitation on the power of both levels of government. ${ }^{86}$ In other words, Article 100(3) refers to bidirectional taxation power (federal to state and state to federal) on profit making enterprises.

\footnotetext{
${ }^{84}$ Art 97 (2) of the FDRE Constitution.

${ }^{85}$ Id., Art 97 (5).

${ }^{86}$ Articles 287 and 288 of India's Constitution are relevant to this subject. Article 287 provides for exemptions from state taxes of electricity consumed by, or sold to, the Government of India. Article 288 exempts from state taxation water and electricity in certain cases. Article 288 (1) provides '... no law of a State...shall impose, or authorize the imposition of, a tax in respect of any water or electricity stored, generated, consumed, distributed or sold by any authority established by any existing law or any law made by Parliament for regulating or developing any inter-State river or river-valley.
} 
Accordingly, federal institutions that are established with profit-oriented objectives must pay land use fee if they operate in states' territories. Those institutions include public enterprises such as Ethio-telecom, Ethiopian Electric Power Corporation, Ethiopian Sugar Corporation, Hotel enterprises, mining enterprises, Ethiopian Aviation Enterprise etc. Those Federal government owned-enterprises make profit by using the land-based resources of the states. However, the states, so far, have neither imposed tax nor fees on the federal government-owned profit making enterprises. ${ }^{87}$

In order to contextualize the application of the intra-governmental tax immunity in the context of water resources and federalism, it is important to use the Great Ethiopian Renaissance Dam (GERD) as an illustration. GERD is being constructed in Benishangul regional state. The GERD is a large dam, with a height of $145 \mathrm{~m}$, storage capacity of $74 \mathrm{BCM}$. The reservoir is more than twice the size of Lake Tana, with a length of $245 \mathrm{~km}$, and is expected to cover an area of $1874 \mathrm{~km}^{2} .{ }^{88}$ The GERD is supplemented by a saddle dam with a length of 5 $\mathrm{km}$, and a height of $245 \mathrm{~m} .{ }^{89}$ The installed capacity of the GERD is $6450 \mathrm{MW}$, with 16 turbines, each expected to generate 375-400 MW. Plans are for power to be traded soon after completion of the dam on the basis of power-purchase agreements signed as early as 2011 with a number of neighboring countries, such as Kenya, Djibouti and Sudan. ${ }^{90}$

The ambition of Ethiopia to make the sale of electricity as an export item qualifies the Ethiopian Electric Power Corporation a profit making public enterprise. The regional state of Benishangul is to lose a vast area of land and large-scale of land will submerge when the filling of the GERD is completed. According to the FDRE and Benishangul Regional state's Constitutions ${ }^{91}$, the regional government is entitled to levy and collect land use fee on profit making public enterprises such as the Ethiopia Electric Power Corporation.

What if a constitutional dispute arises between the state governments and federal profit making enterprises with regard to the levying and administration of land use fee in connection with water works carried out by the federal

${ }^{87}$ Ghebrehiwet Tesfai, The Practice of Fiscal Federalism in Ethiopia: A Critical Assessment 1991-2012: An Institutional Approach, Doctoral Thesis, Faculty of Economics and Social Science, University of Fribourg Switzerland, 2015 (Unpublished), p. 229.

${ }^{88}$ Salman M. A. Salman (2016), 'The Grand Ethiopian Renaissance Dam: the road to the declaration of principles and the Khartoum document', Water International, 41:4, 512527, DOI: 10.1080/02508060.2016.1170374, p.216.

${ }^{89}$ Ibid.

${ }^{90}$ Ana Elisa Cascão \& Alan Nicol (2016), 'GERD: new norms of cooperation in the Nile Basin?', Water International, 41:4, 550-573, DOI: 10.1080/02508060.2016.1180763, p.560.

91 See Art. 47 (2.10) of the Benishangul Regional State Constitution. 
government? In this regard, Article 62(1) of the Constitution has entrusted the House of Federation (hereafter $\mathrm{HoF}$ ) to interpret the Constitution. If any controversy arises on the constitutionality of any statute, decision of an organ of state or public official it shall be decide by the HoF. Accordingly, if any tax statute or practice of the regional government is alleged to contradict with the principle of intergovernmental tax immunity, it shall be decided by the HoF.

\section{Integrated Water Resource Management as Model to Water Governance in Ethiopia's Federal System: An Overview}

The Water Resources Management Proclamation was enacted (in 2000) within the exclusive mandate of the federal government in accordance with Article 55(1) of the Constitution. The Proclamation applies "to water resources management on the water resources that exist in Ethiopia'92. Water resource management is defined as 'activities that include water resources development; utilization, conservation, protection and control'. 93

The Proclamation brings together objectives, principles and legal instruments of the national policy on water resource management. Ethiopia's existing legal and policy framework for water resources management enshrines the basic principles of integrated water resources management. Integrated water resources management is also one of the pillars of Ethiopia's Water Resources Policy. Integrated water resources management envisages the preparation and implementation of Integrated Basin Master Plan Studies.

The previous proclamation, i.e., Water Resources Utilization Proclamation No.92/1994 did not have any provision for integrated water resources management. ${ }^{94}$ For example, it did not take into account a river basin as the appropriate planning unit. ${ }^{95}$ It also lacked institutional backing to implement and reinforce the law. ${ }^{96}$ The presences and roles of multi-stakeholders were unrecognized. ${ }^{97}$

The Water Resources Management Proclamation introduces many changes at institutional and policy levels. It defines the river basin as 'a geographical area,

\footnotetext{
${ }^{92}$ Article 4 of the Water Resources Management Proclamation.

${ }^{93}$ Id., Art 2 (19).

${ }^{94}$ Reta Hailu, Degefa Tolossa \& Getnet Alemu (2018), 'Water institutions in the Awash basin of Ethiopia: the discrepancies between rhetoric and realities', International Journal of River Basin Management, 16:1, 107-121, DOI: 10.1080/15715124.2017.1387126. p.111.

${ }_{95}$ Ibid

${ }^{96}$ Ibid.

${ }^{97}$ Ibid.
} 
described by the watershed limits of a water system including surface and underground water flowing into a common terminus'. ${ }^{98}$ This definition reinforces the concept enshrined in the FDRE Constitution that water is a public good. The Proclamation defines that water is a scarce resource, which has economic and social benefits ${ }^{99}$, and it recognizes the existence of multiple water uses and user rights. ${ }^{100}$

Under the Water Resources Management Proclamation, the right to allocate and apportion water to all regional states regardless of the origin and location is bestowed upon the Ministry of Water Resources (currently called the Ministry of Water, Irrigation and Energy) in its capacity as supervisory body. The legal provisions in the Proclamation with regard to ownership of the resources and its allocation and apportionment clearly show that the development, management, utilization and protection of all water resources in the country fall within the power of the federal government. The literal reading of the words "all waters" in the Proclamation seems to also include intra-state water resources which should have been within the exclusive legislative jurisdiction of states.

The purpose of Water Resources Management Proclamation is 'to ensure that the water resources of the country are protected and utilized for the highest social and economic benefits of the people of Ethiopia, to follow up and supervise that they are duly conserved, ensure that harmful effects of water are prevented, and that the management of water resources is carried out properly'. ${ }^{101}$ The Proclamation also lists some fundamental legal principles that provide a coherent structure for the system.

First, it treats water as public property, as mandated by the FDRE Constitution. It states that all 'water resources of the country are the common property of the Ethiopian people and the state'. ${ }^{102}$ Second, it recognizes that water, along with its ecological attributes, has social and economic value. Especially recognizing water as an economic good justifies charging for its use and the use of the water resources of the country shall be with a permit system. $^{103}$

Third, the Proclamation requires that water management involves multiple uses and there must be a preference among uses. ${ }^{104}$ The Proclamation makes the use of water for domestic use an absolute priority above and over any other

\footnotetext{
${ }^{98}$ See preamble as well as Art. 2 (15) of the Water Resources Management Proclamation.

${ }^{99}$ Id., Art. 6 (1).

${ }^{100}$ Id., Art. 7.

${ }^{101}$ Id., Art. 3.

102 Id., Art. 5.

${ }^{103}$ Id., Art, 6 (4).

${ }^{104}$ Id., Art. 7.
} 
uses. $^{105}$ Fourth, it designates the Integrated Basin Master Plan as a point of reference for the implementation of the social and economic development programs, investment plans and programs and water resources development activities. ${ }^{106}$ The river basin is the territorial unit for water resources planning and management. ${ }^{107}$ These elements of integrated water management in the Proclamation have common features with the Australian and Brazilian models which define the river basin as the territorial unit for water resources management and planning. This avoids the fragmentation of river management and coordination.

Ethiopia's water law principles have incorporated many of the wellestablished principles of international water law. For instance, the principle of fair and equitable utilization of water appears in the River Basin Proclamation as one of the very objectives of the integrated water policy of the country with a view to "using of the basins' water resources for the socio-economic welfare of the people in an equitable and participatory manner, and without compromising the sustainability of the aquatic ecosystem (emphasis added)". ${ }^{108}$ Article 23(1)(c) of the Powers and Duties of the Executive Organs Proclamation in the same manner states that establishing sustainable and integrated administration system is one of the powers of the Ministry of Water, Irrigation and Energy with the aim of facilitating the 'equitable utilization of water resources (emphasis added)'.

Integrated water resources management ${ }^{109}$ principles were adopted at the International Conference on Water and the Environment in $1992 .^{110}$ Integrated water resource management is 'a process which promotes the coordinated development and management of water, land and related resources, in order to maximize the resultant economic and social welfare in an equitable manner

105 Ibid.

106 Id., Art 6 (2).

107 See preamble of the River Basin Proclamation.

108 Id., Art. 4.

${ }^{109}$ Integrated water resources management aims for the integration of management at the river basin level, usually through creating an institutional body (a river basin authority, RBA) reflecting its spatial and functional scope and offering a forum for integrating policy and management. See Ross Beveridge \& Jan Monsees (2012) 'Bridging parallel discourses of Integrated Water Resources Management (IWRM): institutional and political challenges in developing and developed countries', Water International, 37:7, 727-743, DOI: 10.1080/02508060.2012.742713, p.729.

110 Asit K. Biswas, (2004), 'Integrated Water Resources Management: A reassessment', Water Int. , 29, 248-256 in Wilson Sousa and et al., supra note 52, p. 2. 
without compromising the sustainability of vital ecosystems'. ${ }^{111}$ For instance, countries of the European Union have been implementing the Water Framework Directive which requires 'the application of economic instruments and the encouragement of public participation as part of the basin management process'. 112

Ethiopia's pursuits in the path of integrated water management strategy is related with the increasing demand for water among the regional states and the need to utilize water for food and other needs. The river basin concept is thus considered as 'the pillar of the Ethiopia water Policy'. ${ }^{113}$ The integrated water resources management is ideal in arranging mechanisms in reconciling the different priority of water use among potential water uses and states within a river basin system with a view to 'achieve balance and sustainable development of water resources as economic as well as environmental resources'. ${ }^{114}$

The coordination of many stakeholders and their respective different approaches, interests and perceptions were the factors that rendered integrated water resources management necessary. ${ }^{115}$ To this end, the River Basin Councils and Authorities were established as the effective implementation organs of the Ethiopian Water Resources Management Proclamation. ${ }^{116}$ Recently the two basin based water administration structures are replaced by the Basin Development Authority established at national level.

\section{Ethiopia's Water Administration Structures in Light of Integrated Water Resource Management}

Ethiopia's current administrative organs for water management include the Ministry of Water, Irrigation and Energy, ${ }^{117}$ and Basin Development Authority (which has replaced the River Basins High Councils and River Basins High Authorities). The rights and obligations of the basin based authorities are transferred to the Basins Development Authority. It must be noted that administration of intra-state water resources is within the constitutional

${ }^{111}$ Global Water Partnership (2003), Integrated Water Resources Management Toolbox, Version 2. Stockholm: GWP Secretariat in Asit K. Biswas (2004), 'Integrated Water Resources Management: A Reassessment', Water International, 29:2, 248-256, DOI: 10.1080/02508060408691775, p. 249.

${ }^{112}$ Lilian Bechara and Alessandra Magrini, supra note 44, p. 2285.

${ }^{113}$ See Preamble of the River Basin Proclamation, para.2.

${ }^{114}$ Id., para.3.

115 Id., para.4.

${ }^{116}$ Id., para.5.

117 Cumulative reading of Art 2 (7) and Art 8 (2) the Water Resource Management Proclamation. See also art 23 (1) of Powers and Duties of the Executive Organs Proclamation. 
mandates of a regional state, and it is carried out in accordance with federal laws/policies.

In Australia, for example, water related policies are the sole responsibilities of the department of the environment (federal level), and state government agencies are coordinated through the Council of Australian Governments (national level). Likewise, in Brazil, the Department of Water Resources is linked to the Minister of the Environment, at federal level, with similar departments at state level that are entrusted with the responsibility of water related policies.

\subsection{Ministry of Water, Irrigation and Energy}

The Ministry of Water, Irrigation and Energy has the mandate of designing appropriate policy and legal framework for the development and administration of water resources. ${ }^{118}$ The Ministry holds special responsibility for water resources development and river basin planning. Powers and Duties of the Executive Organs Proclamation empowers the Ministry to 'design policies and legal frameworks for the development of water resources and irrigation'. ${ }^{119}$ With regard to water management, the Ministry shall 'undertake basin studies and verify the country's ground and surface water resource potentials in volumetric and quality terms, and facilitate utilization of same'. ${ }^{120}$

Sustainable and integrated administration of water resources within the context of equitable utilization of water resources is under the Ministry's mandate, and it can delegate the same power to the Basins Development Authority. The Ministry also determines 'conditions for optimum and equitable allocation and utilization of water bodies that traverse across or lie between more than one regional states among various uses and regional states' in addition to its duties of undertaking various studies pertaining national and international water resources and negotiating international water based treaties. $^{121}$

\subsection{Basin High Council and Basins Development Authority}

Powers and Duties of the Executive Organs Proclamation has established Basins Development Authority as a federal organ which replaces River Basin High Authorities. Unlike the River Basin Proclamation, ${ }^{122}$ Powers and Duties of the

\footnotetext{
${ }^{118}$ Art. 23 (1) (a) Powers and Duties of the Executive Organs Proclamation.

${ }^{119}$ Ibid.

${ }^{120}$ Id., Art. 23 (1) (b).

${ }^{121}$ Id., Art 23 (1) (f) (g).

${ }^{122}$ According to Art. 4 of the River Basin Proclamation, the overall objective of river basin High Councils and Authorities was to:
} 
Executive Organs Proclamation does not indicate the objective of the establishment of Basins Development Authority. Yet, we can deduce that the same objective is also transferred to Basins Development Authority.

Basin based authorities and direct public participation have been abolished and replaced with centralized decision making process. The River Basin Proclamation had introduced new paradigms, such as decentralization, the use of economic tools for water management and public participation in the decision making process. The issue of participatory interventions in the decision making process at the river basin level was one of the peculiar characteristics of the Ethiopian integrated management model. Unlike the Brazilian model, the Powers and Duties of the Executive Organs Proclamation fails to ensure the participation of important sectors such as relevant regional governments within their respective basins.

In 2007, Ethiopia (in similar fashion like the Brazilian water resources management model) was divided into 12 hydrographic basins to facilitate the administration of water resources,. ${ }^{123}$ The basins are Abbay Basin ${ }^{124}$; Aisha Basin $^{125}$; Awash Basin ${ }^{126}$; Baro-Akobo Basin ${ }^{127}$; Danakil Basin ${ }^{128}$; Genale-Dawa $\operatorname{Basin}^{129}$; Mereb Basin ${ }^{130}$; Ogaden Basin ${ }^{131}$; Omo-Ghibe Basin ${ }^{132}$; Tekeze $\operatorname{Basin}^{133}$; Rift Vally Lakes Basin ${ }^{134}$ and Webi-Shebele ${ }^{135}$ Basin. ${ }^{136}$ Each of the

'promote and monitor the integrated water resources management process in the river basins falling under their jurisdiction with a view to using of the basins' water resources for the socio-economic welfare of the people in an equitable and participatory manner, and without compromising the sustainability of the aquatic ecosystems'.

${ }^{123}$ Id., Art. 2 (1).

${ }^{124}$ Abbay covers Oromia Regional State, Amhara, and Benshangul Gumuz. See Dereje Adeba and et al., supra note 99, p. 317.

125 Aysha covers Somali. Ibid.

${ }^{126}$ Awash covers Oromia Regional State, Southern Nations, Nationalities and Peoples State, Amhara, Afar, Somali, Dire Dawa and Addis Ababa. Ibid. It is the most highly utilized basin in Ethiopia. See Abraha, A.A., 2006. Flood modeling and forecasting for Awash River basin in Ethiopia. Delft: UNESCO-IHE Institute for Water Education in Reta Hailu, Degefa Tolossa \& Getnet Alemu, supra note 94, p.107 .

${ }^{127}$ Baro Akobo Basin, about $31 \%$ of this area falls in Oromia; $9.8 \%$ in Benshangul Gumuz; $24.6 \%$ in Southern Nations Nationalities and People's Regional State (SNNPRS); and $34.3 \%$ in the Gambela Regional State. Ibid.

${ }^{128}$ Denakil covers Amhara, Afar, and Tigray. Ibid.

${ }^{129}$ Genale Dawa covers Oromia Regional State, Southern Nations, Nationalities and Peoples state, and Somali. Ibid.

${ }^{130}$ Mereb covers Tigray. Ibid.

${ }^{131}$ Ogaden covers Somali. Ibid.

${ }^{132}$ Omo Gibe covers Oromia, and Southern Nations, Nationalities and Peoples state. Ibid.

${ }^{133}$ Tekeze covers Tigray. Ibid.

${ }^{134}$ Rift Valley covers Oromia, and Southern Nations, Nationalities and Peoples state. Ibid. 
basin regions is composed of sub-basins that share similar natural, social and economic characteristics.

Basin is defined as 'a geographical area, described by the watershed limits of a water system including surface and underground water flowing into a common terminus'. ${ }^{137}$ Previously, three river basin authorities had been established, namely; Abbay Basin High Council and Authority ${ }^{138}$, Awash Basin High Council and Authority ${ }^{139}$ and Rift Valley Lakes High Council and Authority. ${ }^{140}$ Three more River Basin Authorities had been planned in the Tekeze, Omo-Gibe and Baro-Akobo basins. ${ }^{141}$ Under the Powers and Duties of the Executive Organs Proclamation, the rights and obligations of these Basin Authorities, have been transferred to the Basins Development Authority. ${ }^{142}$

The former river basin authorities had not developed water resource development master plan. ${ }^{143}$ The integrated water resources management did 'not properly cascade down to the lower level as it was fundamentally top down'. ${ }^{144}$ Several stakeholders were not involved in the policy-making process. ${ }^{145}$ The involvement of pertinent stakeholders including local

${ }^{135}$ Wabi Shebelle covers Oromia Regional State, Southern Nations, Nationalities and Peoples state, Harari, and Somali. Ibid.

136 "Basin" means a geographical area, described by the watershed limits of water system including surface and underground water flowing into a common terminus and includes the main basins and their sub-basins of Ethiopia. See Art. 2 (1) of the River Basin Proclamation.

137 Art 3 (15) of the Water Resources Management Proclamation and Art. 2 (1) of River Basin Proclamation.

138 Abbay Basin High Council and Authority Establishment Regulation No. 151/2008. See also Mosello, B., Calow, R. Tucker, J., Parker, H., Alamirew, T., Kebede, S., Alemseged, T. and Gudina, A. (2015) 'Building adaptive water resources management in Ethiopia'. ODI Report, London: ODI, available at https://www.odi.org/ publications/9568-building-adaptive-water-resources-management-ethiopia.

139 Awash Basin High Council and Authority Establishment Regulation No. 156/2008 which replaced the Awash Basin Water Establishment Proclamation No. 129/1998. The total length of the Awash river is approximately $1,250 \mathrm{~km}$.

${ }^{140}$ Rift Valley Lakes High Council and Authority Establishment Council of Ministers Regulation No. 253/2011.

${ }^{141}$ Helen Parker, et. al, A Thirsty Future? Water Strategies for Ethiopia's New Development Era, report, overseas development institutes August 2016, available at http://www.odi.org, p. 30.

${ }^{142}$ Art. 36 (2) Powers and Duties of the Executive Organs Proclamation.

${ }^{143}$ Awash Basin Authority is at final stage of the preparation of the integrated water resource development basin plan.

${ }^{144}$ Reta Hailu, Degefa Tolossa \& Getnet Alemu, supra note 94, p.107.

${ }^{145}$ Ibid. 
community has received little attention. ${ }^{146}$ Investment decisions remained topdown. This means that riparians along the river basins do not have to report on how much water they consume, as investments that are government-led do not require water permits. Consequently, each water-using sector makes 'investment decisions on ad hoc plans, often designed by external consultants, without accounting for other users of the same water resources'. ${ }^{147}$

\subsubsection{Basin High Council}

With the recently introduced reform in the water governance and establishment of the Basin Development Authority, there will be one National Basin High Council instead of basin based High Councils. The Water Resource Management Proclamation had important innovations in its provision for management by water basin units and its creation of Water Basin High Councils. The Water Basin High Council was responsible for decisions about the use of water resources in their designated basins. Article 6(7) of the River Basin Proclamation had designated the Water Basin High Council to play an advisory role to the River Basin Authorities. The National Basins Development Authority need also to bring its policy studies, surveys and researches within basins for approval to the National Basins High Council. ${ }^{148}$ It must be noted that an equivalent advisory institution in the Australian model is the National Water Commission while the advisory body in the Brazilian model is National Water Resources Council at federal level and similar councils at state level.

Under the River Basin Proclamation, the Basin High Council was responsible for approving the river basin plan ${ }^{149}$ and for proposing the amount to be charged for water use ${ }^{150}$ and this right and obligation is transferred to the National Basins High Council. The adoption of the river basin management plans associated with economic instruments is the defining characteristics of the Ethiopian, Brazilian and Australian models and is implemented involving water use permits and water usage charges.

However, Water Basin High Councils at river basin levels have been disestablished, and centralized and undertaking activities at national level will be less effective. The National Basin High Council is the highest organ at national level. Regional states in the different basins should be consulted in the

\footnotetext{
${ }^{146}$ Ibid.

${ }^{147}$ Helen Parker, et. al, supra note 141, p. 30.

148 The Basins Development Authority need first to approve all its studies and basin based master plans. See Art. 32 (5) (a) of Powers and Duties of the Executive Organs Proclamation.

149 Art. 9 (4) of the River Basin Proclamation.

150 Id., Art. 6(3).
} 
planning and construction of water works. ${ }^{151}$ Powers and Duties of the Executive Organs Proclamation 'ensures continuous collaboration between federal and regional governments and other relevant bodies by setting up a forum for effective networking'. ${ }^{152}$ Unlike the Brazilian model, Ethiopian integrated water management system disregards the adoption of integrated management at the river basin level through the establishment of National Basin High Council. The Ethiopian model lags behind in the establishment of the necessary institutional organizations that are supposed to carry out the basic functions of river basin committees established in the Brazilian model.

The disestablishment of Water Basin High Councils at river basin levels demonstrates that, despite the introduction of the integrated water resource management system in the Powers and Duties of the Executive Organs Proclamation, it is at the institutional level that the new system's effectiveness will be tested. The establishment of National Basin High Council and centralized decision making process will cast doubt on the effectiveness of integrated water resources management system. The disestablished Water Basin High Councils had been struggling in implementing integrated water resources management system and the centralization of decision making process can make management of basins difficult unless there is the appropriate balance between decentralization toward basin-level empowerment in the context of the harmonized/centralized aspects of integrated water resources management.

\subsubsection{Basins Development Authority}

It is the independent federal entity responsible for implementing the Ethiopian Water Resources Policy and coordinating the national system of Water Resources Management at basin levels. ${ }^{153}$ Basins Development Authority is responsible for preparing the river master plan; issue permits; give advice and technical support to the Ministry of Water, Irrigation and Energy in relation to dispute settlement and collect water charges from users. ${ }^{154}$ The Basins Development Authority is responsible to the Ministry of Water, Irrigation and Energy. ${ }^{155}$ The Basins Development Authority shall 'undertake policy studies,

${ }^{151}$ Id., Art 9 (5) River Basin Proclamation states that 'without prejudice to the power given to Regional State by law, issue permits applicable to the basin's water use and water works in accordance with Article 15 of this Proclamation, and ensure that the terms of the permits are complied with'. See also Art 32 (5) (g) of Powers and Duties of the Executive Organs Proclamation.

${ }_{152}$ Art 33 (5) (m) of the Powers and Duties of the Executive Organs Proclamation.

${ }^{153}$ The duty of the disestablished River Basin Authorities can be inferred from the preamble of the River Basin Proclamation, Para 5.

${ }^{154}$ Art 32 (5) of Powers and Duties of the Executive Organs Proclamation.

155 Id., Art 33 (14). 
surveys and researches needed to create a conducive environment for the implementation of an integrated water resources management within basins; and follow up implementation upon approval by the relevant body'. ${ }^{156}$

The Basins Development Authority is also empowered to facilitate and undertake activities 'necessary for the implementation of integrated water resources management in basins'. ${ }^{157}$ The Basins Development Authority also ensures that 'projects, activities and interventions related to water in basins, in their content, schedule, impacts and management, are in line with integrated water resource management process'. ${ }^{158}$

The River Basin Proclamation and Powers and Duties of the Executive Organs Proclamation have established four management instruments to help the implementation of Integrated Water Resource Management (IWRM) System. These schemes of implementing IWRM are river basin plans, water permits, water use charges and information systems.

River Basin Plans are master plans that provide guidelines for the management of water resources and for the implementation of the National Water Resources Policy at the river basin level. According to the River Basin Proclamation, River Basin Plan means 'strategic water resources planning with long-term vision in the aim of guarantying equity and sustainability in water resource uses'. 159

The Basins Development Authority is empowered to 'develop plans for the protection and sustainable use of basins; follow up implementation once it is approved by the relevant organ'. ${ }^{160}$ The Basins Development Authority also 'develops and implements basin models in order to guide and support strategic planning of water resources and water administration functions'. ${ }^{161}$ River Basin Plans require data from the Information Systems related to water availability and quality, as well as water demands by category of use and by watershed. ${ }^{162}$ In order to implement river basin plans, Basins Development Authority needs to collect data and analyze and disseminate the same information for "proper planning, administration and steering of water resources in basins'. ${ }^{163}$

\footnotetext{
${ }^{156}$ Id., Art 32 (5) (a).

157 Id., Art 32 (5) (b).

158 Id., Art (5) (c).

159 Art. 2 (8) River Basins Proclamation.

160 Art (5) (d) Powers and Duties of the Executive Organs Proclamation.

161 Id., Art (5) (e).

162 Art. 16 (1) of River Basins Proclamation.

${ }^{163}$ Art (5) (k) Powers and Duties of the Executive Organs Proclamation.
} 
The Proclamation underlines a water permit system as the basis of water resources management 'to ensure quantitative and qualitative control of water uses'. ${ }^{164}$ They represent the right to water or the necessary authorization for water use. The Basins Development Authority issues 'permits applicable to basins' water use and water works, and ensure that the terms of the permits are complied with'. ${ }^{165}$ The issuance of water permits relating to water use or water works should take into consideration 'the basin's future perspective in line with integrated water resources management processes'. ${ }^{166}$ They demand quantitative and qualitative data (from the Information System) on water availability, upstream and downstream users. Water use charges are established that consider the water permits granted, and are intended to make water use more efficient and to reduce pollution. They also provide financial resources. ${ }^{167}$

The main goal of the information system is 'to produce, systemize and provide data and information regarding water resources conditions at the river basin level, including quality and quantity for different uses, land use maps, slope, vegetation cover, point discharges, registers of users and other relevant information for water management'. ${ }^{168}$ The Powers and Duties of the Executive Organs Proclamation imposes an obligation on Basins Development Authority to 'collect data and analyze and disseminate the same information for proper planning, administration and steering of water resources in basins'. ${ }^{169}$

In the same manner, the River Basin Proclamation had imposed an obligation on the River Basin Authorities to prepare basic information system 'in order to guide and support the basin water resources strategic planning and water management functions'. ${ }^{170}$ The Basin Information System must include basin data such as the quantity and quality of water resources of the basin; the level of the water demand within the basin; and the existing and planned major water infrastructures. ${ }^{171}$ It must be noted that, the River Basin Authorities lacked resources and authority to coordinate investments, allocate water and resolve conflicts. $^{172}$

\footnotetext{
${ }^{164}$ B. P. F. Braga and et al., supra note 1, p. 617.

${ }^{165}$ Art (5) (g) Powers and Duties of the Executive Organs Proclamation.

166 Art. 15 (3) of the River Basin Proclamation.

${ }^{167}$ See Art. 31 of the Ethiopian Water Resources Management Council of Ministers Regulation No. 115/2005. Federal Negarit Gazeta, 3057-3068 , 2005.

${ }^{168}$ B. P. F. Braga and et al., supra note 1, p. 618.

${ }^{169}$ Art (5) (k) Powers and Duties of the Executive Organs Proclamation .

170 Art. 16 (1) of the River Basin Proclamation.

${ }^{171}$ Id, Art. 16 (2).

${ }^{172}$ Helen Parker, et. al, supra note 141, p. 9.
} 


\section{Inter-state Water Dispute Resolution}

According to the Powers and Duties of the Executive Organs Proclamation, it is the Ministry of Water, Irrigation and Energy that serves as dispute resolution center in the event of inter-state water disputes. According to the Proclamation, the Basins Development Authority shall 'give advice and technical support to the Ministry of Water, Irrigation and Energy on dispute resolution in relation to the allocation and use of water resources in basins'. ${ }^{173}$

Previously, the Basin High Council managed water use disputes between regional states in the basin; and the Council served as a river water dispute resolution center. ${ }^{174}$ The scope of the mandate of the Basin High Council was limited only to those water resources within the federal mandate. Thus, there is the need for Regulations and Directives as to how the Ministry of Water, Irrigation and Energy can resolve issues of conflict. In the absence of legal rules on dispute settlement, it becomes difficult to manage and resolve conflicting interests among riparian communities along the regional states so that they can have sustainable agreement and peace. This is, inter alia, because different agencies and actors make investment decisions, both public and private, with often-conflicting plans to develop the same water resources. ${ }^{175}$

River Basin Authorities had struggled to resolve these conflicts without the political authority to influence investment decisions or the means to assess impacts and trade-offs. ${ }^{176}$ For instance, the Awash River Basin ${ }^{177}$ is experiencing increased tension between downstream and upstream irrigators along the regional states, and between water for agriculture, energy and domestic use. ${ }^{178}$ The regional government of Oromia is investing in its own irrigation projects in Fentale and Tibila, with no reference to upstream and downstream users. ${ }^{179}$ In the Awash Basin, competing and conflicting interests of

${ }^{173}$ Art (32) (5) (I) of Powers and Duties of the Executive Organs Proclamation.

${ }_{174}$ Article 6(6) of the River Basin Proclamation.

${ }^{175}$ Mosello, B., Calow, R. Tucker, J., Parker, H., Alamirew, T., Kebede, S., Alemseged, T. and Gudina, A. (2015) 'Building adaptive water resources management in Ethiopia'.

ODI Report, London: ODI, available at https://www.odi.org/ publications/9568-buildingadaptive-water-resources-management-ethiopia in Helen Parker, et. al, supra note 141, p. 21 .

176 Ibid.

${ }^{177}$ The Awash Basin is a prime example of emerging and increasing competition over water resources.

Approximately 15.7 million people live in the Awash, about 17\% of Ethiopia's population. See, Helen Parker and et al, supra note 141, p. 19.

${ }^{178}$ Id., p. 7.

${ }^{179}$ Id., p. 20. 
various regions have aggravated the scarcity of water resources. ${ }^{180}$ A number of studies have attributed the cause of conflicts in the Awash River Basin to the introduction of various large scale commercial agricultural schemes along river courses. $^{181}$

This prompts a question whether the regional states in the basin can, from the outset make decisions on development activities over such inter-state water resources such as Awash, which is within the exclusive mandate of the federal government. If this occurs, an issue arises whether such projects violate constitution thereby increasing tension between/among states. Such activities may indeed give rise for dispute between federal and state governments.

\section{Concluding Remarks}

Poor water management has led to conflicts between upstream and downstream users in international watercourses. The same cannot be ruled out in national water resources. Competing demands should thus be mediated through rules that set out the terms and conditions under which different groups can access and use water. The blend between the utilization of water resources and federalism in Ethiopia through integrated water resources management is at its infant stage and it is partly attributable to the lack of well-developed water law.

There are limited provisions in the FDRE Constitution and other laws on the legal framework related to water governance in Ethiopia. The power to legislate and administer water is vested on the federal government and limited legislative and administrative jurisdiction is left for the regional states. In order to manage water, Ethiopia has introduced a legal foundation for integrated water resources managements system. However, the implementation of the integrated water resource management model is still incomplete, and its administration and decision making process has been confined at federal level.

Unlike Brazilian and Australian Models, the Ethiopian integrated water management legal framework is yet in the course of struggling to set up the necessary institutions to ensure an effective, coordinated and integrated approach to water management. The disestablishment of river basin authorities and replacing them with national Basins Development Authority can make the

${ }^{180}$ Dereje Adeba et al. (2016), 'Economic evaluation of the proposed alternatives of interbasin water transfer from the Baro Akobo to Awash basin in Ethiopia', Sustain. Water Resour. Manag. 2:313-330 DOI 10.1007/s40899-016-0058-3, p. 322.

${ }^{181}$ Desalegn Chemeda Edossa et al., (2005), Indigenous systems of conflict resolution in Oromia, Ethiopia, International workshop on 'African Water Laws: Plural Legislative Frameworks for Rural Water Management in Africa', 26-28, Johannesburg, South Africa, p. 2. 
implementation of integrated water management system difficult unless there are schemes that can facilitate response to specific basin needs. This challenge is indeed evident in light of the weak legal and institutional set-ups in the management and resolution of inter-state water disputes. 